Психология. Журнал Высшей школы экономики,

2017. T. 14. № 1. C. 61-87. DOI: 10.17323/1813-8918.2017.1.61.87.

\title{
АДАПТАЦИЯ МЕТОДИК ИССЛЕДОВАНИЯ СУИЦИДАЛЬНЫХ АСПЕКТОВ ЛИЧНОСТИ
}

\author{
К.А. ЧИСТОПОЛЬСКАЯ \\ С.Н. ЕНИКОЛОПОВ ${ }^{\mathrm{c}}$ Е.Л. НИКОЛАЕВ
}

\begin{abstract}
${ }^{a}$ Московский научно-исследовательский институт психиатрии - филиал Федерального государственного бюджетного учреждения «Федеральный медицинский исследовательский центр психиатрии и наркологии» Министерства здравоохранения Российской Федерации. 107076, Москва, ул. Потешная, Ә. 3, стр. 10

${ }^{b}$ Федеральное государственное бюджетное образовательное учреждение высшего образования «Московский государственный психолого-педагогический университет, 127051, Россия, Москва, ул. Сретенка, д. 29

' Федеральное государственное бюджетное научное учреждение «Научный иентр психического здоровья», 115522, Россия, Москва, Каширское шоссе, д. 34

${ }^{d}$ ФГБОУ ВПО «Чувашский государственный университет им. И.Н. Ульянова», 428015, Россия, Чувашская Республика, г. Чебоксары, Московский проспект, д. 15
\end{abstract}

\section{Резюме}

Представлены результаты адаптации на русскоязычной выборке методик «Шкала душевной боли» (The Psychache Scale - Holden et al., 2001), «Причины для жизни» (Reasons for Living Inventory - Linehan et al., 1983) и «Опросник причин попытки суицида» (Reasons for Attempting Suicide Questionnaire - Johns, Holden, 1997). Был осуществлен перевод с последующим анкетированием психически здоровых лиц в возрасте от 16 до 26 лет, находящихся в состоянии относительного психологического благополучия (150 человек в Москве, 66 юношей, 84 девушек, а также 221 человек в Чебоксарах, 50 юношей, 171 девушка). При оценке психометрических свойств русскоязычных вариантов адаптируемых тестов получены хорошие результаты по воспроизводимости структур факторов, составляющих шкалы методик, их надежности и конструктной валидности. С помощью метода главных компонент с вращением варимакс подтверждено удовлетворительное соответствие структуры русскоязычных версий опросников структуре оригиналов. После доработки русскоязычные варианты данных методик смогут использоваться для оценки степени суицидального риска и мотивации суицидального поведения у школьников старших классов и студентов вузов, обучающихся по образовательным программам разных уровней, а также в исследовательских целях для изучения причин суицидального поведения.

Ключевые слова: суицидальное поведение, адаптация методик, внутренняя согласованность шкал, воспроизводимость, валидность.

\section{Введение}

Суицидальное поведение - социальное явление, подчиняющееся устойчивым закономерностям, связанным с экономическими, культурно-историческими и этническими особенностями целых государств и 
их отдельных регионов. Французский социолог Эмиль Дюркгейм считал, что нет такого человеческого переживания, которое не могло бы быть субъективным поводом для самоубийства (Дюркгейм, 2013).

По данным Всемирной организации здравоохранения, отмечается значительное повышение числа суицидальных попыток и самоубийств среди молодых людей в возрасте от 15 до 24 лет. До конца 1960-х гг. они составляли относительно незначительную часть от общего числа суицидов. С 1960 г. их частота среди подростков увеличилась на $265 \%$. Среди молодежи смертность, связанная с суицидом, занимает первое место среди причин смерти (Войцех, 2007).

В настоящее время в Российской Федерации наблюдается нисходящий тренд суицидальной активности с максимумом в возрасте от 15 до 34 лет с пиком в 27 лет: в 2012 г. число суицидов в этой узкой возрастной группе достигало 11.47 на 100 тыс. населения, а общее число суицидов в 2012 г. - 20.5 на 100 тыс. населения, и это только зарегистрированные случаи. Хотя их уровень понемногу снижается каждый год, высоким остается уровень латентных суицидов, так называемых случайных смертей: случайных отравлений, случайных удушений, падений с высоты, огнестрелов и пр. В тот же год количество таких случаев достигло 31.7 на 100 тыс. населения, что в сумме дает ужасающую цифру 52.2 смерти на 100 тыс. населения (Морев и др., 2014).

Увеличение количества суицидальных попыток в молодежной среде большинство исследователей рассматривают как одну из острей- ших социальных проблем современного общества. В Российской Федерации до настоящего времени нет разработанной и утвержденной на государственном уровне программы превенции самоубийств.

Для успешного предотвращения попыток суицида необходимо всесторонне изучать и анализировать их побудительные мотивы. В этом могут помочь надежные психологические тесты, выявляющие и оценивающие особенности суицидального поведения. Для данной цели в зарубежных исследованиях широко используются такие методики, как The Psychache Scale (PS; Holden et al., 2001), Reasons for Living Inventory (RFL 48; Linehan et al., 1983) и Reasons for Attempting Suicide Questionnaire (RASQ; Johns, Holden, 1997). Одним из неоценимых преимуществ вышеназванных психологических методик является то, что они, как отмечают их создатели, не имеют в своем применении возрастных, гендерных и этнокультуральных ограничений.

«Шкала душевной боли» (The Psychache Scale) основана на концепции Э. Шнейдмана. Душевная боль, по его мнению, самым непосредственным образом связана с фрустрацией жизненных психологических потребностей, ее интенсивность определяет внутреннее амбивалентное отношение индивида к суицидальному акту: «Если прекращение своего потока сознания - это то, к чему движется суицидальный человек, то душевная боль - это то, от чего он стремится убежать» (Шнейдман, 2001, с. 354). В российской суицидологии концепцию психалгии (душевной боли) развивала А.Г. Амбрумова, 
которая стажировалась в Центре профилактики суицидов у Э. Шнейдмана и Н. Фарбероу (Амбрумова, 1978). «Шкала душевной боли» признана наиболее приемлемым психологическим конструктом для общей оценки душевной боли, достигшей значительного осознания (Meerwijk, Weiss, 2016). Надежность, воспроизводимость и валидность данной шкалы подтверждены на выборках молодых респондентов без суицидальных наклонностей (Flamenbaum, Holden, 2007; DeLisle, Holden, 2009) и на выборках стационарных пациентов с попытками самоубийства в анамнезе (Holden, Kroner, 2003; Olié et al., 2010), а также на выборке заключенных (Mills et al., 2005). Тот факт, что психалгия является основополагающим предиктором суицидальных действий, убедительно показан в ряде исследований (Pereira et al., 2010; Patterson, Holden, 2012; Troister et al., 2015). Установлено, что у индивидов, имеющих в анамнезе попытки самоубийства, интенсивность душевной боли значительно выше, чем у лиц, не склонных к совершению суицида. «Шкала душевной боли» может использоваться для оценки степени суицидального риска (Flamenbaum, Holden, 2007; Olié et al., 2010).

Существует еще одна шкала душевной боли, «Orbach and Mikulincer Mental Pain Questionnaire» (Orbach et al., 2003), она оценивает преимущественно спецификацию этой боли по 9 субшкалам, в которых указаны ее причины и поведенческие паттерны, а не душевную данность, которую пациент зачастую не способен приписать некоему событию или явлению (mental pain vs psychache).
Субшкалы следующие: необратимость, потеря контроля, нарциссическая рана, переполненность чувствами, замирание, отчуждение от себя, смятение, пустота и социальная дистанция. Методика состоит из 45 пунктов, т.е. довольно объемна. Тем не менее мы не отвергаем возможность в будущем апробировать и эту шкалу. Авторы значительно расширяют феноменологию психологической боли и список ситуаций, в которых она проявляется.

В отличие от «Шкалы душевной боли», оценивающей один из основополагающих предикторов самоубийства, методика «Причины для жизни» (Reasons for Living Inventory) позволяет исследовать факторы, способствующие предотвращению суицидальных действий. RFL 48, основанная на концепции взаимодействия биологических и социальных факторов научения Т. Милона и опирающаяся на теоретические представления М. Линехан о когнитивноповеденческих паттернах, широко используется исследователями суицидального поведения во многих странах мира: так, структура методики подтвердилась на итальянской (Ronconi et al., 2009), колумбийской (Garcia Valencia et al., 2009) и малайской (Aishvarya et al., 2014) выборках суицидентов. Ее надежность, воспроизводимость и валидность доказаны при тестировании представителей различных этнических групп респондентов. Исследования проводились с участием лиц, не имеющих суицидальных наклонностей (Linehan et al., 1983; Osman et al., 1998; Choi, Rogers, 2010), и лиц с пограничными расстройствами и попытками суицида в анамнезе (Linehan et 
al., 1983; Malone et al., 2000; Heisel, Flett, 2004; Aishvarya et al., 2014). Методика «Причины для жизни» позволяет выявлять суицидальные наклонности, а также прогнозировать риск совершения повторной попытки самоубийства у суицидентов (Linehan et al., 1983).

В зависимости от иерархии потребностей конкретной личности желание покончить с собой может быть как глубоко внутренне выстраданным, так и поверхностно ситуационным. А.Г. Амбрумова в поздних работах развивала идею мотива неблагополучия и мотива конфликта, а также монологического и диалогического суицида, не отрицая душевной боли, которую испытывают оба типажа суицидентов (Амбрумова, Калашникова, 1998). «Опросник причин попытки суицида» (Reasons for Attempting Suicide Questionnaire) позволяет с большой долей вероятности оценить мотивацию как планируемой, так и уже совершенной попытки самоубийства (Levinger, Holden, 2014). RASQ создан на основе методики Дж. Бэнкрофта, базирующейся на когнитивно-поведенческой теории суицида (Bancroft et al., 1976). Данная методика широко использовалась в 1970-е и 1980-е гг. для тестирования наркозависимых пациентов с эпизодами передозировки в анамнезе. При анкетировании лиц, совершивших попытку самоубийства, факторный анализ опросника Reasons for Attempting Suicide Questionnaire выявил наличие двух внутренних шкал (Johns, Holden, 1997; Holden, DeLisle, 2006), а у лиц, не имевших суицидальных проявлений, - трех (Holden, McLeod, 2000). Масштабное исследование с участи- ем совершивших в недавнем прошлом попытку суицида 1646 человек из 13 стран позволило выделить четыре внутренние шкалы, однако их воспроизводимость не была подтверждена эмпирически (Hjelmeland et al., 2002). По мнению М. Алексиса и Ф. Клонски, неустойчивая факторная структура RASQ может объясняться тем, что не имеющие суицидальных наклонностей респонденты могут ошибаться при трактовке своих гипотетических намерений, что может «затенить» подлинные мотивации попыток самоубийства (Alexis, Klonsky, 2013). Тем не менее данный опросник является признанным психологическим инструментом, позволяющим оценивать мотивы суицидальных действий (Levinger, Holden, 2014).

Склонные к самоубийству индивиды, как правило, имеют негативный опыт прошлого, не удовлетворены своим настоящим, не видят перспектив в будущем (Лайнен, 2008). Исследования с помощью опросника временно́й перспективы личности Ф. Зимбардо подтверждают, что совершившие попытки самоубийства индивиды более негативно, чем лица без суицидальных наклонностей, оценивают свое прошлое, а в настоящем придерживаются фаталистических взглядов, причем, помимо повышенных показателей негативной временно́й перспективы (Сырцова, Митина, 2008), суициденты характеризуются снижением показателей отдельных компонентов позитивной временно́й перспективы позитивного прошлого и гедонизма (Чистопольская, Ениколопов, 2013). Хотя обширное метаисследование показало, что добросовестность и суицидальное 
поведение связаны отрицательно (Bogg, Roberts, 2004), наше предыдущее исследование (Чистопольская, Ениколопов, 2013) не выявило значимых различий в показателях шкалы будущего методики Ф. Зимбардо между выборкой нормы и людьми в остром постсуициде. В концепции Ф. Зимбардо будущее нейтрально и отражает в основном готовность выполнять обязательства и работать на достижение отдаленной цели, отдавая ей предпочтение перед сиюминутными удовольствиями (корреляция с показателями по шкале добросовестности «Большой пятерки» $\mathrm{r}=0.57$ (Zimbardo, Boyd, 1999). Мы затрудняемся однозначно интерпретировать расхождения с зарубежными данными, однако полагаем, что в трудной жизненной ситуации будущее, как его понимает Ф. Зимбардо, все же способно защитить человека от суицидальных действий. Соответственно, мы предполагаем, что негативная временна́я перспектива будет положительно связана с душевной болью и мотивами попытки, а позитивная временна́я перспектива - с защитными мотивами антисуицидального поведения.

Отрицательная перспектива будущего находит свое отражение и в одном из компонентов когнитивной модели депрессии А. Бека (депрессивной триады), включающей негативную оценку себя, мира и будущего (Бек, Фримен, 2002). Разработанная А. Беком шкала «Безнадежность» оценивает восприятие индивидом событий ближайшего и отдаленного будущего. Лица, планирующие или совершившие попытки самоубийства, как правило, не видят перспектив в жизни, будущее пред- ставляется им безысходным (Журавлева и др., 2015а, 2015б), что, в свою очередь, приводит к самоощущению, что суицид является единственно возможным выходом из сложившейся ситуации. Соответственно, на наш взгляд, безнадежность должна положительно коррелировать с душевной болью, мотивами попытки и отрицательно - с защитными факторами.

Суициденты зачастую требуют повышенного внимания к себе со стороны окружающих, испытывают трудности в общении, конфликтны, подвержены резким колебаниям настроения (Лайнен, 2008). По данным популяционного исследования А. Стравински и Р. Бойер, субъективное переживание одиночества оказалось одним из наиболее значимых факторов предсказания суицидального риска (Stravinski, Boyer, 2001). Это также подтверждается клиническими исследованиями и наблюдениями (Амбрумова, Калашникова, 1996; Soubrier, 1993). Известно, что для отдельных душевных расстройств (пограничное личностное расстройство, избегающее поведение) переживания одиночества, отчужденности являются характерными или даже ключевыми. Поэтому в нашем исследовании мы привлекли методику «Многомерная шкала восприятия социальной поддержки» Г. Зимета (Zimet et al., 1988) в адаптации Н.А. Сироты (Сирота и др., 2001), предположив, что все шкалы (поддержка семьи, значимого другого и друзей) будут отрицательно коррелировать с душевной болью, мотивами попытки суицида и положительно - c антисуицидальными факторами. 
Суициденты, как правило, обладают слабыми навыками совладания со стрессовыми воздействиями. Они демонстрируют либо более пассивный, либо более зависимый по сравнению с общей популяцией стиль решения межличностных проблем и рассматривают самоубийство как единственно возможный выход из кризисной ситуации (Лайнен, 2008). Однако выбор в пользу смерти всегда осуществляется в условиях очевидной альтернативы, заключающейся в возможности продолжения жизни, несмотря на наличие кризисного состояния. Благодаря навыкам вовлеченности, контроля и принятия риска, которые являются составляющими жизнестойкости, человек может обогатить свой личностный потенциал и развить способности справляться со стрессом (Леонтьев, Рассказова, 2006). Мы предположили, что жизнестойкость будет отрицательно связана с душевной болью и мотивами суицидальной попытки и положительно - с антисуицидальными факторами.

Позитивно ценностное отношение человека к смерти формируется, как правило, на фоне борьбы с психической болью, которая, достигнув предела переносимости, способна привести антивитально настроенного индивида к совершению суицидальных действий. В кризисной ситуации суицидальный человек стремится к прекращению своего актуального состояния, видя в смерти возможность избавления от страданий, - самоубийство становится для него самоцелью (Амбрумова, Калашникова, 1998). Что касается веры в жизнь после смерти и попадания в рай, наше исследование пока- зало, что люди в остром постсуициде не верят в спасение; только у людей с несколькими попытками эта вера была выше, чем в норме (Чистопольская, Ениколопов, 2013, 2015). Религиозность, по крайней мере, постфактум играет защитную функцию, однако когда психологическое неблагополучие слишком велико, религия перестает действовать как защита и встает на сторону суицидальности. При этом люди в остром постсуициде больше, чем лица без суицидальных наклонностей, боятся и смерти, и самого акта самоубийства (Чистопольская и др., 2012; Чистопольская, Ениколопов, 2013; Журавлева и др., 2015a). Данный факт выглядит парадоксальным лишь на первый взгляд. С одной стороны, страх смерти является защитным фактором от совершения суицидальных действий, а с другой - от него самого требуется защита, так как, являясь болезненным переживанием, он способствует снижению уровня психологического благополучия и самостигматизации (Чистопольская, Ениколопов, 2015). Тем не менее страхи смерти значительно ниже у людей в остром пресуициде (Журавлева и др., 2015б), что соответствует теории Т. Джойнера о приобретенном бесстрашии к смерти (Ribeiro et al., 2014) и теории разрушения буфера культурной тревоги (Pyszczynski, Kesebir, 2011). Поэтому при оценке суицидального риска надо учитывать оба варианта: и повышенный, и пониженный страхи смерти, как правило, свидетельствуют о душевном неблагополучии и могут приводить к негативным поведенческим реакциям. Опросник «Отношение к смерти», основанный на теории 
управления смыслом П. Вонга (Wong et al., 1994), и шкала «Страх личной смерти» (Florian, Kravetz, 1983), оценивающая неприятие данной темы на сознательном уровне, адаптированные нами (Чистопольская и др., 2014), позволяют оценить факторы суицидального риска. Мы предположили, что принятие смерти как бегства и страх забвения как самый неблагоприятный из страхов смерти будут положительно связаны с душевной болью и мотивами суицидальной попытки, а избегание смерти и прочие страхи - с защитными, антисуицидальными факторами.

Описанные выше методики позволяют с разных сторон описать феномен суицида, однако предъявление их суициденту единым блоком является проблематичным из-за утомляемости психиатрических пациентов. С другой стороны, опросник «Шкалы динамического контроля суицидального риска» (ШДК) и пиктографический экспресс-тест «Риск суицидального действия», разработанные С.В. Харитоновым (Харитонов и др., 2014, 2016), а также Шкала суицидальных мыслей А. Бека (Бек, Фримен, 2002) рассматривают исключительно суицидальный потенциал и уровень бесстрашия, задают респонденту вопросы, что называется, «в лоб». Это может помочь в клинической практике при установленном раппорте, но человек на скрининге часто склонен занижать свои показатели. К тому же эти методики не апеллируют к мотивам, защитным факторам и субъективной переносимости душевной боли. В российской суицидологии давно назрела необходимость компактных методик, охваты- вающих данные явления. Т.С. Павлова (2013), в частности, среди описанных ею методик, которые ей хотелось бы иметь для работы с суицидальной молодежью, упомянула и адаптируемую нами методику «Причины для жизни». И методики «Шкала душевной боли», «Причины для жизни» и «Опросник причин попытки суицида», на наш взгляд, справляются с этой функцией, а «Шкала душевной боли» и «Причины для жизни» тоже могут применяться как скрининговые. Внедрение данных методик в психологическую работу с молодежью поможет разработать стратегии превенции и методологические основы психологической коррекции лиц, склонных к самоубийству или уже совершивших суицидальные попытки. Именно в коррекции, помимо остроты состояния пациента, становятся важны наполненность его суицидальных переживаний и доступность ресурсов.

Целью данной работы является адаптация методик The Psychache Scale, Reasons for Living Inventory и Reasons for Attempting Suicide Questionnaire на русскоязычной выборке психически здоровых и психологически стабильных лиц молодого возраста, а также проверка конструктной валидности этих шкал.

\section{Объект и методы исследования}

В тестировании приняли участие 150 респондентов в возрасте от 16 до 26 лет г. Москвы (таблица 1) и 221 студент экономического, психологического и стоматологического факультетов Чувашского государственного университета им. И.Н. Ульянова (таблица 2). 
Социально-демографическая структура московской выборки

\begin{tabular}{|c|c|c|c|c|c|c|}
\hline $\begin{array}{l}\text { Гендерная } \\
\text { принадлежность }\end{array}$ & \multicolumn{3}{|c|}{ Мужчины n = 66} & \multicolumn{3}{|c|}{ Женщины n = 84} \\
\hline $\begin{array}{l}\text { Средний возраст } \\
\text { в годах }(\mathrm{M} \pm \mathrm{SD})\end{array}$ & \multicolumn{3}{|c|}{$21.12 \pm 3.02$} & \multicolumn{3}{|c|}{$20.70 \pm 3.09$} \\
\hline $\begin{array}{l}\text { Социальный } \\
\text { статус }\end{array}$ & $\begin{array}{c}\text { Школь- } \\
\text { ники } \\
\text { X-XI } \\
\text { классов } \\
\text { n = } 12\end{array}$ & $\begin{array}{c}\text { Студенты } \\
\text { I-VI } \\
\text { курсов } \\
\text { вузов } \\
\text { n = } 29\end{array}$ & $\begin{array}{c}\text { Аспиранты } \\
\text { 1-2-го года } \\
\text { обучения } \\
\text { n }=25\end{array}$ & $\begin{array}{c}\text { Школь- } \\
\text { ники } \\
\text { X-XI } \\
\text { классов } \\
\text { n = } 19\end{array}$ & $\begin{array}{c}\text { Студенты } \\
\text { I-VI } \\
\text { курсов } \\
\text { вузов } \\
\text { n }=43\end{array}$ & 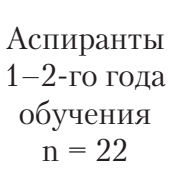 \\
\hline
\end{tabular}

Таблица 2

Социально-демографическая структура чебоксарской выборки

\begin{tabular}{|c|c|c|c|c|c|c|}
\hline $\begin{array}{l}\text { Гендерная } \\
\text { принадлежность }\end{array}$ & \multicolumn{3}{|c|}{ Мужчины n = 50} & \multicolumn{3}{|c|}{ Женщины n = 171} \\
\hline $\begin{array}{l}\text { Средний возраст } \\
\text { в годах }(\mathrm{M} \pm \mathrm{SD})\end{array}$ & \multicolumn{3}{|c|}{$19.8 \pm 1.4$} & \multicolumn{3}{|c|}{$19.7 \pm 1.1$} \\
\hline $\begin{array}{l}\text { Социальный } \\
\text { статус }\end{array}$ & $\begin{array}{l}\text { Эконо- } \\
\text { мисты } \\
\mathrm{n}=14\end{array}$ & $\begin{array}{c}\text { Психо- } \\
\text { логи } \\
\mathrm{n}=20\end{array}$ & $\begin{array}{c}\text { Стомато- } \\
\text { логи } \\
\mathrm{n}=16\end{array}$ & $\begin{array}{l}\text { Эконо- } \\
\text { мисты } \\
\mathrm{n}=65\end{array}$ & $\begin{array}{c}\text { Психо- } \\
\text { логи } \\
\mathrm{n}=51\end{array}$ & $\begin{array}{c}\text { Стомато- } \\
\text { логи } \\
\mathrm{n}=55\end{array}$ \\
\hline
\end{tabular}

Московская выборка формировалась из студентов и аспирантов биологического факультета МГУ им. М.В. Ломоносова, лечебного факультета 1-го МГМУ им. И.М. Сеченова, лечебного и медико-биологического факультетов РНИМУ им. Н.И. Пирогова, факультета юриспруденции и ювенальной юстиции и факультета социального страхования, экономики и социологии труда РГСУ, факультета автоматизации и информатики МГГУ, а также учащихся X-XI классов средней общеобразовательной школы № 1613 и многопрофильного технического лицея № 1501 г. Москвы.

Мы также взяли чебоксарскую выборку, так как этот регион имеет свою «суицидальную историю», хоть и не является сейчас остросуицидальным.

На первом этапе исследования были созданы русскоязычные версии опросников The Psychache Scale, Reasons for Living Inventory и Reasons for Attempting Suicide Questionnaire. B качестве привлеченных к данной процедуре специалистов выступали профессиональные психологи, свободно владеющие русским и английским языками. Вначале был осуществлен симметричный перевод текста методик с языка оригинала на русский (Peters, 2011; Vreeman et al., 2013) с бережным отношением к смысловым конструкциям: не текств-текст, а смысл-в-смысл. После 
обратного перевода носителем языка оба варианта прошли экспертную оценку, и симметричный перевод был скорректирован до более точного соответствия оригиналу. Для большего соответствия текста измеряемым характеристикам был проведен небольшой предварительный опрос, когда респондентов спрашивали, как они понимают вопросы, и текст опять-таки прошел небольшую корректировку. После чего начался второй этап исследования, в рамках которого респондентам предлагалось письменно заполнить 9 психологических тестов, предъявляемых в следующем порядке.

1. Опросник временно́й перспективы личности (Zimbardo Time Perspective Inventory) Ф. Зимбардо (Zimbardo, Boyd, 1999) в адаптации А. Сырцовой, О.В. Митиной (Сырцова, Митина, 2008). Опросник основан на модели жизненного пространства К. Левина и включает 56 утверждений, оцениваемых по пятибалльной шкале Лайкерта. На основе эмпирического анализа выделено пять аспектов временно́й перспективы: негативное прошлое, позитивное прошлое, гедонистическое настоящее, фаталистическое настоящее и ориентация на будущее.

2. Многомерная шкала восприятия социальной поддержки (Multidimensional Scale of Perceived Social Support) Г. Зимета (Zimet et al., 1988) в адаптации Н.А. Сироты и В.М. Ялтонского (Сирота и др., 2001). Эта шкала основана на идее, что для совладающего поведения человека очень важна поддержка его близких. Шкала содержит 12 утверждений и оценивает восприятие наличия и эффективности социальной под- держки по трем аспектам: поддержка семьи, поддержка друзей и поддержка значимого другого. В качестве значимого другого может выступать авторитетная для данного индивида личность из его микросоциального окружения.

3. Краткая версия теста «Жизнестойкость» (Hardiness Survey) С. Мадди (Maddi, 2004) в адаптации Е.Н. Осина и Е.И. Рассказовой (Осин, Рассказова, 2013). Тест «Жизнестойкость» разработан С. Мадди в рамках экзистенциального направления психологических исследований и адаптирован на русскоязычной выборке Д.А. Леонтьевым и Е.И. Рассказовой (2006). Краткая версия содержит 24 высказывания и оценивает общий уровень жизнестойкости. Тест содержит три шкалы: вовлеченность, контроль и принятие риска. Выраженность этих компонентов и общая мера жизнестойкости в целом способствуют более здоровому ответу на стрессовые ситуации (Осин, Рассказова, 2013).

4. Шкала «Безнадежность» (Beck Hopelessness Scale) A. Бека (Бек, Фримен, 2002). Шкала «Безнадежность» разработана А. Беком (Beck et al., 1974) в рамках его когнитивной теории, в которой безнадежность рассматривается как основополагающий компонент в системе негативного восприятия событий ближайшего и отдаленного будущего. Методика представляет собой 20 утверждений, которые отражают отношение респондентов к своему будущему, формирующееся на основе их настоящего и прошлого опыта. Она зарекомендовала себя как валидный инструмент для оценки суицидального радикала личности. 
5. «Шкала душевной боли» (The Psychache Scale) Р. Холдена (Holden et al., 2001). Шкала разработана на основе концепции психической боли Э. Шнейдмана. Данный опросник содержит 13 утверждений, девять из них описывают наличие и характеристику душевной боли, например, «У меня щемит внутри» или «Моя душевная боль хуже любой физической боли», а четыре - ее интенсивность, например, «Я не могу больше терпеть эту боль». Утверждения оцениваются респондентами по пятибалльной шкале Лайкерта. Чем выше суммарный балл опрашиваемого по данному тесту, тем выше риск совершения им суицидальной попытки.

6. Опросник «Причины для жизни» (Reasons for Living Inventory) M. Линехан (Linehan et al., 1983). Методика представляет собой форму самоотчета, состоящую из мотивировок, почему человек не готов совершить самоубийство, даже если задумывается о нем. Опросник состоит из 48 утверждений, оцениваемых по шестибалльной шкале Лайкерта, и включает шесть шкал: способность к выживанию и совладанию (24 утверждения, например: «Я люблю жизнь», «Я достаточно забочусь о себе, чтобы жить»), ответственность перед семьей (7 утверждений, например: «Я ощущаю ответственность и обязательства перед своей семьей»), забота о детях (3 утверждения, например: «Я хочу увидеть, как растут мои дети»), боязнь суицида (7 утверждений, например: «Я боюсь неизвестности», «Я боюсь смерти»), боязнь общественного осуждения (3 утверждения, например: «Другие люди решат, что я слаб(-а) и себялюбив(-а)») и моральные запреты (4 утверждения, например: «Мои религиозные убеждения это запрещают»). Важно отметить инструкцию к опроснику. Она выглядела так: «Многие люди задумывались о самоубийстве хотя бы раз в жизни. Другие никогда не рассматривали его в качестве альтернативы. Здесь приведены причины, по которым люди порой не совершают самоубийство. Нам интересно, насколько важна каждая из причин лично для вас. Даже если вы никогда серьезно не обдумывали самоубийство и уверены, что не будете о нем думать, все же оцените каждое утверждение». Респондентам предлагался мысленный эксперимент, нужно было представить себя в роли суицидента и отметить, какие причины удержали бы его от этого поступка.

7. Краткая версия опросника «Отношение к смерти» (Death Attitude Profile-Revised) П. Вонга (Wong et al., 1994) в адаптации К.А. Чистопольской, С.Н. Ениколопова и др. (Чистопольская и др., 2012, 2014). Краткая версия (CFI = 0.961; $\mathrm{SRMR}=0.038 ; \mathrm{RMSEA}=0.047)$ состоит из 16 утверждений, оцениваемых респондентами по семибалльной шкале Лайкерта, и включает пять шкал: принятие-приближение смерти, избегание темы смерти, страх смерти, принятие смерти как бегства и нейтральное принятие смерти. Методика предназначена для оценки отношения индивида к смерти как к явлению, его взглядов на смерть, его способа принятия темы смерти на сознательном уровне.

8. Краткая версия шкалы «Страх личной смерти» (Fear of Personal Death Scale) В. Флориана и С. Кравеца (Florian, Kravetz, 1983) в адаптации 
К.А. Чистопольской, С.Н. Ениколопова и др. (Чистопольская и др., 2012, 2014). Краткая версия ( CFI = 0.943; $\mathrm{SRMR}=0.045 ;$ RMSEA $=0.060)$ содержит 21 утверждение, оцениваемое респондентами по семибалльной шкале Лайкерта, и предполагает внутриличностное, межличностное и надличностное измерения, которые, в свою очередь, делятся на шкалы. Внутриличностное измерение включает две шкалы: последствия для личности и последствия для тела. Межличностное измерение включает две шкалы: последствия для близких и страх забвения, или, иными словами, страх потери социальной идентичности. Надличностное измерение представлено шкалой трансцендентных последствий. Опросник «Страх личной смерти» предназначен для исследования неприятия смерти и изучения причин, по которым человек вероятнее всего отторгает ее.

9. «Опросник причин попытки суицида» (Reasons for Attempting Suicide Questionaire) Д. Джонса и Р. Холдена (Johns, Holden, 1997) содержит 14 утверждений-мотивировок совершения суицидальных действий, оцениваемых по пятибалльной шкале Лайкерта. Методика включает две шкалы: манипулятивная мотивация/обвинение окружающих (8 утверждений, например: «Я хотел(-а) кого-то напугать» или «я хотел(-а), чтобы люди пожалели о том, как обращались со мной») и внутреннее смятение (6 утверждений, например: «Я пытался(-ась) освободиться от мучающих меня мыслей»). Инструкция выглядела следующим образом: «Пожалуйста, отметьте, насколько вы согласны с этими утверждениями. Они описывают причины, по которым вы могли бы попытаться покончить с собой. Даже если желания свести счеты с жизнью у вас никогда не возникало, попытайтесь мысленно представить себе акт самоубийства и оцените предложенные утверждения». Так же, как и с опросником «Причины для жизни», респондент должен был «симулировать» суицидальность и совершить мысленный эксперимент, чтобы ответить на вопросы.

На третьем этапе исследования оценивались психометрические свойства русскоязычных версий методик The Psychache Scale, Reasons for Living Inventory и Reasons for Attempting Suicide Questionnaire.

Статистическая обработка данных проводилась с использованием программы SPSS 20. Сначала анализировалась структура опросников на сводной московско-чебоксарской выборке ( $\mathrm{n}=371)$ с помощью эксплораторного факторного анализа методом главных компонент с вращением варимакс. Для проверки конструктной валидности производилось вычисление коэффициента корреляции Пирсона между шкалами адаптируемых и стандартизированных методик (только на чебоксарской выборке, $\mathrm{n}=221$ ). Для оценки внутренней согласованности шкал использовался коэффициент $\alpha$ Кронбаха.

\section{Результаты исследования и обсуждение}

При факторном анализе «Шкалы душевной боли» по методу главных компонент с вращением варимакс был извлечен единственный фактор 
с собственным значением 7.198, объясняющий $55.4 \%$ совокупной дисперсии. Была извлечена только одна компонента, и решение не могло быть повернуто. «Шкала душевной боли» показала высокую степень надежности $(\alpha$ Кронбаха $=0.929)$.

Баллы по «Шкале душевной боли» положительно коррелировали с показателями негативной временно́й перспективы: «Негативным прошлым», «Гедонистическим настоящим» и «Фаталистическим настоящим», а также с баллами по шкалам «Безнадежность», «Принятие смерти как бегства» и «Страх забвения». «Страх забвения» является специфическим для суицидентов (Чистопольская, Ениколопов, 2013). С баллами всех субшкал «Многомерной шкалы восприятия социальной поддержки» Г. Зимета и теста «Жизнестойкость», а также со шкалой «Будущее» опросника временно́й перспективы баллы «Шкалы душевной боли» находились в обратной зависимости (таблица 3).

Следует подчеркнуть, что негативная связь душевной боли с жизнестойкостью достаточно сильна и почти достигает уровня $r=0.6$, в то время как связь с безнадежностью значительно ниже $(r=0.37)$. Это свидетельствует о большей близости и взаимодополняемости конструктов жизнестойкости и душевной боли, нежели душевной боли и безнадежности.

Выявлен средний уровень положительной связи баллов по шкале «Душевная боль» с баллами по шкалам «Манипулятивная мотивация/ обвинение окружающих» $(r=0.3)$ и «Внутреннее смятение» $(r=0.41)$, что свидетельствует о почти равном вкладе душевной боли как в мотив конфликта, так и в мотив неблагополучия, по крайней мере, на уровне симуляции (ведь мы спрашивали здоровых несуицидальных людей о предполагаемых мотивах суицида); и отрицательной - с баллами по шкале «Способность к выживанию и совладанию» (таблица 4), что также подтверждает понимание феномена душевной боли как проблемы внутренних ресурсов личности. Полученные нами результаты согласуются с данными зарубежных исследователей, выявивших статистически достоверную позитивную связь душевной боли с безнадежностью и депрессией (Flamenbaum, Holden, 2007; DeLisle, Holden, 2009; Troister et al., 2015), негативными событиями прошлого (Meerwijk, Weiss, 2016), манипулятивной мотивацией и внутренним смятением (Levinger, Holden, 2014). Отечественными психологами показано, что негативные события прошлого и фатализм положительно связаны с душевными переживаниями, выражающимися в обиде на окружающих и в депрессии (Сырцова, Митина, 2008). Выявлено также, что у лиц с алкогольной зависимостью, совершивших попытки суицида, психическая боль позитивно связана с принятием смерти как бегства от жизненных проблем и негативно - со способностью к выживанию и совладанию со стрессом (Журавлева и др., 2015а).

Положительная связь психической боли с безнадежностью и отрицательная - с ориентацией на будущее подтверждают постулат когнитивной теории А.Т. Бека о триаде дисфункциональных убеждений для депрессии и суицида (Бек, Фримен, 
Таблица 3

Оценка конструктной валидности шкалы «Душевная боль» на чебоксарской выборке

$$
(\mathrm{n}=\mathbf{2 2 1})
$$

\begin{tabular}{|c|c|c|}
\hline \multicolumn{2}{|c|}{ Шкалы стандартизированных методик } & Шкала «Душевная боль», $r$ \\
\hline \multirow{5}{*}{$\begin{array}{l}\text { Временна́я } \\
\text { перспектива } \\
\text { личности }\end{array}$} & Негативное прошлое & $0.41^{* * *}$ \\
\hline & Позитивное прошлое & -0.04 \\
\hline & Гедонистическое настоящее & $0.24^{* * *}$ \\
\hline & Фаталистическое настоящее & $0.34^{* * *}$ \\
\hline & Ориентация на будущее & $-0.16^{*}$ \\
\hline \multirow{3}{*}{$\begin{array}{l}\text { Социальная } \\
\text { поддержка }\end{array}$} & Поддержка семьи & $-0.23^{* * *}$ \\
\hline & Поддержка друзей & $-0.14^{*}$ \\
\hline & Поддержка значимого другого & $-0.25^{* * *}$ \\
\hline \multirow{4}{*}{ Жизнестойкость } & Вовлеченность & $-0.54 * * *$ \\
\hline & Контроль & $-0.48^{* * *}$ \\
\hline & Принятие риска & $-0.52^{* * *}$ \\
\hline & Общая жизнестойкость & $-0.57 * * *$ \\
\hline \multicolumn{2}{|l|}{ Безнадежность } & $0.37 * * *$ \\
\hline \multirow{5}{*}{$\begin{array}{l}\text { Отношение } \\
\text { к смерти }\end{array}$} & Принятие-приближение смерти & 0.10 \\
\hline & Избегание темы смерти & $-0.17 * *$ \\
\hline & Страх смерти & 0.12 \\
\hline & Принятие смерти как бегства & $0.25^{* * *}$ \\
\hline & Нейтральное принятие & 0.05 \\
\hline \multirow{5}{*}{$\begin{array}{l}\text { Страх личной } \\
\text { смерти }\end{array}$} & Последствия для личности & 0.03 \\
\hline & Последствия для тела & 0.08 \\
\hline & Трансцендентные последствия & 0.13 \\
\hline & Последствия для близких & 0.20 \\
\hline & Страх забвения & $0.14^{*}$ \\
\hline
\end{tabular}

${ }^{*} p<0.05,{ }^{* *} p<0.01,{ }^{* * *} p<0.001$.

2002), а ее позитивная связь с мотивами обвинения окружающих и внутреннего смятения - концепцию Э. Шнейдмана о ведущей роли психалгии в суицидогенезе (Holden et al., 2001).

Стоит отметить положительную корреляцию с показателем «Гедони- стического настоящего» - эта «лукавая» шкала в данном случае показала свою негативную сторону - отчасти она измеряет нетерпеливость, импульсивность и склонность к риску, а не только ориентацию на удовольствие, «вкус к жизни» и поиск новых ощущений. 
Таблица 4

Оценка взаимосвязи шкал адаптируемых методик $(\mathrm{n}=371)$

\begin{tabular}{|l|c|c|c|c|c|c|}
\hline \multirow{2}{*}{\multicolumn{1}{|c|}{ Шкалы адаптируемых методик }} & \multicolumn{5}{|c|}{ Номера шкал адаптируемых методик, $r$} \\
\cline { 2 - 7 } & 2 & 3 & 4 & 5 & 6 \\
\hline 1. Душевная боль & $-0.27^{* * *}$ & 0.07 & -0.13 & $0.30^{* * *}$ & $0.41^{* * *}$ \\
\hline Причины для жизни & 1 & $0.19^{* *}$ & $0.66^{* * *}$ & $-0.19^{* *}$ & $-0.20^{* *}$ \\
\hline $\begin{array}{l}\text { 2. Способность к выживанию и } \\
\text { совладанию }\end{array}$ & & 1 & $0.40^{* * *}$ & 0.1 & 0.01 \\
\hline $\begin{array}{l}\text { 3. Боязнь суицида, осуждения и } \\
\text { моральный запрет }\end{array}$ & & & 1 & -0.02 & -0.06 \\
\hline $\begin{array}{l}\text { 4. Ответственность перед семьей и } \\
\text { детьми }\end{array}$ & & & & & $0.65^{* * *}$ \\
\hline Смьсль попьтки суицида & & & & & & 1 \\
\hline $\begin{array}{l}\text { 5. Манипулятивная мотивация/ } \\
\text { Обвинение окружающих }\end{array}$ & & & & & \\
\hline 6. Внутреннее смятение & & & & & \\
\hline
\end{tabular}

${ }^{*} p<0.05,{ }^{* *} p<0.01,{ }^{* * *} p<0.001$.

Русскоязычная версия опросника «Причины для жизни» включает только три внутренние шкалы - это было наилучшим решением в нашей сводной выборке (таблица 5). При проведении анализа по методу главных компонент с вращением варимакс извлечено три фактора с собственными значениями $12.854,4.783$ и 2.304. Они объясняли $41.5 \%$ совокупной дисперсии. Эти три шкалы мы назвали «Способность к выживанию и совладанию», «Боязнь суицида, осуждения и моральный запрет» и «Ответственность перед семьей и детьми». При этом нам пришлось убрать два пункта: один не имел смысла и имел слабую нагрузку на вторую шкалу («Я слишком спокойный, чтобы убить себя»), а второй пункт имел слабую нагрузку и не имел смысла в третьей шкале («Я не верю, будто все может стать настолько плохо и безнадежно, что я предпочел(-ла) бы умереть»). В целом смысл оригинальной методики (Linehan et al., 1983) сохранен, при том что шесть факторов лучше всего интерпретировались объединенными в три, некоторые пункты имеют невысокую и/или двойную нагрузку, но это закономерно, учитывая большое количество пунктов и относительно небольшое количество респондентов. Данный результат можно считать удовлетворительным в качестве предварительной адаптации.

У всех шкал русскоязычной версии методики «Причины для жизни» высокие коэффициенты надежности ( $\alpha$ Кронбаха для первой шкалы 0.925 , для второй -0.844 , для третьей -0.867$)$.

Шкалы опросника «Причины для жизни» делятся на две группы: 
Таблица 5

Факторная структура методики «Причины для жизни» $(\mathrm{n}=371)$

\begin{tabular}{|c|c|c|c|c|c|c|c|}
\hline \multirow{2}{*}{ Пункт } & \multicolumn{2}{|c|}{ Факторные нагрузки } & \multirow{2}{*}{ Пункт } & \multicolumn{3}{c|}{ Факторные нагрузки } \\
& 1 & 2 & 3 & & 1 & 2 & 3 \\
\hline Q4 & $\mathbf{0 . 7 0 8}$ & -0.077 & 0.195 & Q41 & 0.124 & $\mathbf{0 . 6 4 6}$ & -0.015 \\
\hline Q35 & $\mathbf{0 . 7 0 0}$ & 0.081 & 0.130 & Q23 & -0.010 & $\mathbf{0 . 6 4 1}$ & 0.251 \\
\hline Q32 & $\mathbf{0 . 6 8 1}$ & -0.012 & 0.173 & Q26 & -0.045 & $\mathbf{0 . 6 1 4}$ & 0.078 \\
\hline Q24 & $\mathbf{0 . 6 7 5}$ & 0.061 & 0.299 & Q46 & -0.132 & $\mathbf{0 . 5 9 5}$ & -0.270 \\
\hline Q37 & $\mathbf{0 . 6 7 5}$ & 0.023 & 0.177 & Q27 & 0.056 & $\mathbf{0 . 5 8 7}$ & 0.310 \\
\hline Q3 & $\mathbf{0 . 6 6 7}$ & 0.017 & 0.069 & Q38 & 0.053 & $\mathbf{0 . 5 8 4}$ & 0.017 \\
\hline Q13 & $\mathbf{0 . 6 6 7}$ & -0.002 & 0.207 & Q34 & 0.234 & $\mathbf{0 . 5 1 9}$ & 0.207 \\
\hline Q22 & $\mathbf{0 . 6 6 5}$ & -0.047 & 0.222 & Q33 & -0.228 & $\mathbf{0 . 4 9 4}$ & -0.032 \\
\hline Q44 & $\mathbf{0 . 6 4 0}$ & 0.083 & 0.067 & Q6 & 0.149 & $\mathbf{0 . 4 7 0}$ & 0.183 \\
\hline Q20 & $\mathbf{0 . 6 3 8}$ & 0.138 & 0.344 & Q15 & 0.077 & $\mathbf{0 . 4 4 5}$ & 0.032 \\
\hline Q12 & $\mathbf{0 . 6 3 4}$ & 0.009 & 0.327 & Q18 & -0.287 & $\mathbf{0 . 4 1 2}$ & -0.083 \\
\hline Q2 & $\mathbf{0 . 6 2 7}$ & -0.065 & 0.194 & Q5 & 0.106 & $\mathbf{0 . 3 9 7}$ & 0.367 \\
\hline Q14 & $\mathbf{0 . 6 2 3}$ & -0.042 & 0.210 & Q25 & 0.358 & $\mathbf{0 . 3 6 8}$ & 0.099 \\
\hline Q19 & $\mathbf{0 . 6 1 2}$ & 0.174 & 0.150 & Q16 & 0.327 & 0.099 & $\mathbf{0 . 7 1 2}$ \\
\hline Q40 & $\mathbf{0 . 6 1 0}$ & 0.042 & 0.098 & Q30 & 0.327 & 0.117 & $\mathbf{0 . 7 0 6}$ \\
\hline Q42 & $\mathbf{0 . 6 0 7}$ & 0.255 & -0.014 & Q28 & 0.211 & 0.236 & $\mathbf{0 . 6 8 3}$ \\
\hline Q45 & $\mathbf{0 . 5 6 8}$ & 0.268 & 0.145 & Q1 & 0.297 & 0.001 & $\mathbf{0 . 6 8 1}$ \\
\hline Q29 & $\mathbf{0 . 5 3 5}$ & 0.035 & 0.207 & Q9 & 0.269 & 0.073 & $\mathbf{0 . 6 7 9}$ \\
\hline Q10 & $\mathbf{0 . 5 1 1}$ & 0.116 & 0.253 & Q11 & 0.379 & 0.102 & $\mathbf{0 . 6 4 1}$ \\
\hline Q17 & $\mathbf{0 . 4 8 5}$ & -0.011 & 0.240 & Q47 & 0.211 & 0.266 & $\mathbf{0 . 5 5 8}$ \\
\hline Q39 & $\mathbf{0 . 3 7 8}$ & 0.305 & 0.301 & Q21 & 0.357 & 0.043 & $\mathbf{0 . 5 3 3}$ \\
\hline Q36 & $\mathbf{0 . 3 6 9}$ & 0.066 & 0.034 & Q7 & -0.059 & 0.036 & $\mathbf{0 . 5 0 1}$ \\
\hline Q31 & 0.102 & $\mathbf{0 . 6 9 2}$ & 0.076 & Q48 & 0.242 & 0.367 & $\mathbf{0 . 3 8 9}$ \\
\hline Q43 & 0.195 & $\mathbf{0 . 6 7 8}$ & 0.040 & Q8 & 0.251 & 0.024 & $\mathbf{0 . 2 8 8}$ \\
\hline
\end{tabular}

«содержательные», т.е. осмысленные причины для жизни (способность к выживанию и совладанию, ответственность перед семьей и детьми) и «формальные», носящие характер осуждения и ограничения (боязнь суицида, общественного осуждения и моральные запреты). Выявлены положительные связи баллов «содержательных» шкал с баллами шкал «Позитивное прошлое», «Будущее», «Гедонистическое настоящее», «Поддержка семьи», «Поддержка друзей», «Поддержка значимого другого», все шкалы теста «Жизнестойкость». 
Таблица 6

Оценка конструктной валидности методики «Причины для жизни» $(\mathrm{n}=221)$

\begin{tabular}{|c|c|c|c|}
\hline \multirow[b]{2}{*}{$\begin{array}{c}\text { Шкалы стандартизированных } \\
\text { методик }\end{array}$} & \multicolumn{3}{|c|}{ Шкалы методики «Причины для жизни», $r$} \\
\hline & $\begin{array}{c}\text { Способность к } \\
\text { выживанию и } \\
\text { совладанию }\end{array}$ & $\begin{array}{c}\text { Боязнь суицида, } \\
\text { осуждения и } \\
\text { моральный } \\
\text { запрет }\end{array}$ & $\begin{array}{c}\text { Ответственность } \\
\text { перед семьей и } \\
\text { детьми }\end{array}$ \\
\hline \multicolumn{4}{|l|}{ Временна́я перспектива личности } \\
\hline Негативное прошлое & $-0.20 * *$ & 0.1 & -0.08 \\
\hline Позитивное прошлое & $0.21^{* *}$ & $0.20^{* *}$ & $0.37^{* * *}$ \\
\hline Гедонистическое настоящее & $0.16^{*}$ & 0.03 & $0.13^{*}$ \\
\hline Фаталистическое настоящее & $-0.25^{* * *}$ & $0.16^{*}$ & -0.05 \\
\hline Ориентация на будущее & $0.28^{* * *}$ & 0.05 & $0.19^{* *}$ \\
\hline \multicolumn{4}{|l|}{ Социальная поддержка } \\
\hline Поддержка семьи & $0.46^{* * *}$ & $0.19 * *$ & $0.56^{* * *}$ \\
\hline Поддержка друзей & $0.32^{* * *}$ & 0.08 & $0.31^{* * *}$ \\
\hline Поддержка значимого другого & $0.43^{* * *}$ & 0.05 & $0.42^{* * *}$ \\
\hline \multicolumn{4}{|l|}{ Жизнестойкость } \\
\hline Вовлеченность & $0.43^{* * *}$ & -0.02 & $0.28 * * *$ \\
\hline Контроль & $0.40^{* * *}$ & -0.01 & $0.23^{* * *}$ \\
\hline Принятие риска & $0.35^{* * *}$ & -0.10 & $0.15^{*}$ \\
\hline Общая жизнестойкость & $0.43^{* * *}$ & -0.05 & $0.24^{* * *}$ \\
\hline Безнадежность & $-0.64^{* * *}$ & 0.08 & $-0.40^{* * *}$ \\
\hline \multicolumn{4}{|l|}{ Отношение к смерти } \\
\hline Принятие-приближение смерти & -0.01 & $0.33^{* * *}$ & $0.15^{*}$ \\
\hline Избегание темы смерти & $0.36^{* * *}$ & $0.18^{* *}$ & $0.32^{* * *}$ \\
\hline Страх смерти & $0.32^{* * *}$ & $0.48^{* * *}$ & $0.37^{* * *}$ \\
\hline Принятие смерти как бегства & $-0.25^{* * *}$ & $0.20 * *$ & -0.05 \\
\hline Нейтральное принятие & $0.17^{*}$ & $-0.26^{* * *}$ & 0.10 \\
\hline \multicolumn{4}{|l|}{ Страх личной смерти } \\
\hline Последствия для личности & $0.46^{* * *}$ & 0.08 & $0.29 * * *$ \\
\hline Последствия для тела & 0.08 & $0.43^{* * *}$ & $0.15^{*}$ \\
\hline Трансцендентные последствия & $0.22^{* * *}$ & $0.34^{* * *}$ & $0.26^{* * *}$ \\
\hline Последствия для близких & $0.39^{* * *}$ & $0.17^{* *}$ & $0.55^{* * *}$ \\
\hline Страх забвения & -0.13 & $0.22^{* *}$ & -0.06 \\
\hline
\end{tabular}

${ }^{*} p<0.05,{ }^{* *} p<0.01,{ }^{* * *} p<0.001$. 
Отрицательные корреляции баллов «содержательных» шкал отмечены с баллами шкал «Безнадежность» и «Принятие смерти как бегства» (только шкала «Способность к выживанию и совладанию»). Более высокий уровень корреляционных связей наблюдался с защитными страхами смерти (шкалы «Последствия для личности» и «Последствия для близких»), более низкий с неблагоприятными страхами смерти (шкалы «Последствия для тела» (шкала «Ответственность перед семьей и детьми» и «Трансцендентные последствия»). Также меньше, чем «формальная» шкала, эти шкалы коррелируют с общим «Страхом смерти», повышена корреляция обеих шкал с «Избеганием темы смерти», есть положительная корреляция с «Нейтральным принятием смерти» («Способность к совладанию и выживанию»). Это свидетельствует о связи «содержательных» причин для отказа от суицида с ориентацией на жизнь и малой долей дезадаптивных страхов смерти: люди с высокими баллами по этим шкалам ориентируются в первую очередь на то хорошее, что у них есть в жизни, и дорожат им (близкими, собой, своими стремлениями, добрыми воспоминаниями), хотя и не испытывают чрезмерного страха смерти (Чистопольская и др., 2014).

Баллы по «формальной» шкале («Боязнь суицида, осуждения и моральные запреты»), в отличие от «содержательных», хотя и невысоко коррелировали с баллами «Позитивного прошлого», также имели небольшую положительную корреляцию с «Фаталистическим настоящим», небольшую корреляцию со шкалой «Поддержка семьи», но больше всего корреляций было со шкалами, измеряющими отношение к смерти: среднего уровня корреляция с «Принятием-приближением смерти», низкая - $\mathrm{c}$ «Избеганием темы смерти», средняя - со «Страхом смерти», положительная с «Принятием смерти как бегства», отрицательная - с «Нейтральным принятием смерти», средняя корреляция с «Последствиями смерти для тела», «Трансцендентными последствиями», низкая - $\mathrm{c}$ «ооледствиями для близких» и корреляция со «Страхом забвения». Человек, который набирает высокие показатели по этой шкале, явно больше думает о смерти и скорее всего уже как минимум размышлял о суициде как возможном выходе из неблагоприятной ситуации. «Формальные» причины отказа от суицида сочетаются с дезадаптивными страхами смерти и дезадаптивным отношением к ней, компульсивным избеганием смерти, что должно учитываться при анализе индивидуальных случаев.

Отрицательная корреляционная связь отмечена между баллами шкалы «Способность к выживанию и совладанию» и шкал «Душевная боль» и «Внутреннее смятение» из «Опросника причин попытки суицида», что свидетельствует о сильном защитном факторе этого конструкта (таблица 4). «Содержательные» шкалы связаны между собой на высоком уровне $(r=0.66)$, связь «Способности к совладанию и выживанию» с «Боязнью суицида» мала $(r=0.19)$, однако корреляция «Ответственности перед семьей и детьми» с «Боязнью суицида» значительно выше $-r=0.4$. Это также 
может свидетельствовать о том, что, если человек задумывается о последствиях суицида для близких, он уже, скорее всего, размышляет о суициде как возможности, и это также стоит иметь в виду при разборе конкретных случаев.

Русскоязычная версия «Опросника причин попытки суицида» включает две внутренние шкалы (таблица 7).

При проведении факторного анализа были извлечены два фактора с собственными значениями 6.563 и 1.524. Они объясняли $57.8 \%$ совокупной дисперсии. Структура русскоязычной версии «Опросника причин попытки суицида» соответствует структуре оригинала (Johns, Holden, 1997), за исключением пункта 1 («Я хотел(-а) наказать себя»), который лег на первую шкалу («Манипулятивная мотивация») вместо второй («Внутреннее смятение»), при анализе согласованности его исключение в той и другой шкале давало незначительное улучшение, и мы решили вовсе исключить его из анализа. Кроме того, пункт 6 «Я искал(a) помощи, потому что не справлялся(-ась) с чувствами и трудностями» уверенно нагрузился на шкалу «Внутреннее смятение». Вероятно, ощущение беспомощности сыграло более значимую роль в его отнесении к «Внутреннему смятению», чем «крик о помощи», который, в представлении авторов, более свойствен «Манипулятивная мотивация». Обе шкалы на русскоязычной выборке показали хорошую внутреннюю согласованность ( $\alpha$ Кронбаха 0.897 для шкалы «Манипулятивной мотивации» и 0.837 для «Внутреннего смятения»).

Выявлена невысокая, но положительная связь баллов обеих шкал опросника с баллами по шкалам «Негативное прошлое», «Фаталистическое настоящее»; «Внутреннее смятение» опять-таки проявилось и в низкой положительной корреляции с «Гедонистическим настоящим» (таблица 8). Кроме того, невысокие положительные корреляции наблюдались с «Принятием смерти как бегства», «Трансцендентными последствиями» и «Страхом забвения». Негативная корреляционная связь отмечена с баллами всех субшкал теста «Жизнестойкость», причем корреляции баллов шкалы «Манипулятивная

Таблица 7

Факторная структура «Опросника причин попытки суицида» $(\mathrm{n}=371)$

\begin{tabular}{|c|c|c|c|c|c|}
\hline \multirow{2}{*}{$\begin{array}{c}\text { Пункт } \\
\text { опросника }\end{array}$} & \multicolumn{2}{|c|}{ Факторные нагрузки } & \multirow{2}{*}{$\begin{array}{c}\text { Пункт } \\
\text { опросника }\end{array}$} & \multicolumn{2}{|c|}{ Факторные нагрузки } \\
& 1 & 2 & & 1 & 2 \\
\hline Q4 & 0.806 & 0.197 & Q1 & 0.513 & 0.224 \\
\hline Q5 & 0.779 & 0.258 & Q12 & 0.164 & 0.860 \\
\hline Q10 & 0.745 & 0.212 & Q11 & 0.166 & 0.806 \\
\hline Q9 & 0.742 & 0.116 & Q13 & 0.231 & 0.780 \\
\hline Q3 & 0.720 & 0.312 & Q6 & 0.325 & 0.728 \\
\hline Q8 & 0.716 & 0.240 & Q14 & 0.420 & 0.429 \\
\hline Q7 & 0.605 & 0.515 & Q2 & 0.396 & 0.415 \\
\hline
\end{tabular}


Оценка конструктной валидности «Опросника причин попытки суицида» $(\mathrm{n}=221)$

\begin{tabular}{|c|c|c|}
\hline \multirow{2}{*}{$\begin{array}{c}\text { Шкалы стандартизированных } \\
\text { методик }\end{array}$} & \multicolumn{2}{|c|}{ Шкалы «Опросника причин попытки суицида», $r$} \\
\hline & $\begin{array}{c}\text { Манипулятивная мотивация/ } \\
\text { Обвинение окружающих }\end{array}$ & Внутреннее смятение \\
\hline \multicolumn{3}{|l|}{ Временна́я перспектива личности } \\
\hline Негативное прошлое & $0.14^{*}$ & $0.17^{*}$ \\
\hline Позитивное прошлое & 0.10 & 0.04 \\
\hline Гедонистическое настоящее & 0.01 & $0.14^{*}$ \\
\hline Фаталистическое настоящее & $0.22 * *$ & $0.18^{* *}$ \\
\hline Ориентация на будущее & -0.01 & -0.06 \\
\hline \multicolumn{3}{|l|}{ Социальная поддержка } \\
\hline Поддержка семьи & -0.03 & -0.08 \\
\hline Поддержка друзей & $-0.14^{*}$ & -0.04 \\
\hline Поддержка значимого другого & -0.10 & -0.04 \\
\hline \multicolumn{3}{|l|}{ Жизнестойкость } \\
\hline Вовлеченность & $-0.21^{* *}$ & $-0.27^{* * *}$ \\
\hline Контроль & $-0.25^{* * *}$ & $-0.28^{* * *}$ \\
\hline Принятие риска & $-0.15^{* *}$ & $-0.23^{* *}$ \\
\hline Общая жизнестойкость & $-0.22 * *$ & $-0.28 * * *$ \\
\hline Безнадежность & $0.27 * * *$ & $0.20^{* *}$ \\
\hline \multicolumn{3}{|l|}{ Отношение к смерти } \\
\hline Принятие-приближение смерти & 0.13 & 0.05 \\
\hline Избегание темы смерти & -0.02 & -0.08 \\
\hline Страх смерти & 0.04 & -0.01 \\
\hline Принятие смерти как бегства & $0.21 * *$ & $0.19 * *$ \\
\hline Нейтральное принятие & -0.07 & 0.05 \\
\hline \multicolumn{3}{|l|}{ Страх личной смерти } \\
\hline Последствия для личности & 0.03 & 0.06 \\
\hline Последствия для тела & 0.10 & -0.05 \\
\hline Трансцендентные последствия & $0.15^{*}$ & $0.14^{*}$ \\
\hline Последствия для близких & 0.01 & 0.08 \\
\hline Страх забвения & $0.25^{* * *}$ & $0.16^{*}$ \\
\hline
\end{tabular}

${ }^{*} p<0.05,{ }^{* *} p<0.01,{ }^{* * *} p<0.001$. 
мотивация/Обвинение окружающих» с показателями жизнестойкости несколько ниже, чем корреляции баллов шкалы «Внутреннее смятение», и наоборот, шкала «Безнадежность» коррелирует с «Манипулятивной мотивацией» чуть выше, чем с «Внутренним смятением». Кроме того, эти шкалы, как уже было сказано, положительно на среднем уровне коррелируют со шкалой «Душевной боли» (выше со «Внутренним смятением») и со «Способностью к совладанию и выживанию», т.е. респонденты чувствовали, что «Безнадежность» более свойственна «Манипулятивной мотивации», а «Душевная боль» - «Внутреннему смятению».

Все это свидетельствует о том, что суицид в первую очередь - проблема внутренних ресурсов, «утраты Я» (Соколова, 2015), нежели пессимистичного взгляда на будущее, а отсутствие поддержки близких лишь в малой степени является побудительной причиной для суицида.

\section{Выводы}

Версии опросников The Psychache Scale, Reasons for Living Inventory и Reasons for Attempting Suicide Questionnaire, адаптированные на русскоязычной выборке лиц без суицидальных проявлений, имеют высокую внутреннюю согласованность шкал, они надежны и воспроизводимы. Их валидность подтверждена эмпирически. Данные психологические тесты могут применяться для исследования мотивации суицидального поведения и оценки степени суицидального риска у школьников старших классов, студентов, обучающихся в высших учебных заведениях по образовательным программам разных уровней. Методики «Шкала душевной боли» и «Причины для жизни» могут применяться как скрининговые инструменты, а все три опросника - в клинике для диагностики суицидальности и антисуицидальных тенденций пациентов с антивитальными переживаниями и в постсуициде, которая уже проводится нами (Журавлева и др., 2015а, 2015б).

Касательно наших гипотез о связи данных методик с уже применяемыми в суицидологической практике не все они были подтверждены. Отчасти мы это объясняем тем, что исследование являлось симуляцией суицидальных тенденций, т.е. людей просили представить, как бы они повели себя, будь они суицидальными, а это все же не то же самое, что действительно пребывать в суицидальном кризисе.

Ограничения данного исследования заключаются в том, что выборка респондентов была невелика и опросник «Причины для жизни» можно считать прошедшим успешную, но предварительную адаптацию. На данный момент проводится исследование по его окончательной адаптации на широкой студенческой выборке. 


\section{Литература}

Амбрумова, А. Г. (1978). Психалгия в суицидологической практике. В кн. Актуальные проблемь суищидологии (с. 73-98). М.: Московский НИИ психиатрии.

Амбрумова, А. Г., Калашникова, О. Э. (1996). Психологические аспекты одиночества. Социальная и клиническая психиатрия, 6(3), 53-63.

Амбрумова, А. Г., Калашникова, О. Э. (1998). Клинико-психологические аспекты самоубийства. Социальная и клиническая психиатрия, 4(8), 65-77.

Бек, А., Фримен, А. (2002). Когнитивная психотерапия расстройств личности. Практикум по психотерапии. СПб.: Питер.

Войцех, В. Ф. (2007). Что мы знаем о суиииде. М.: Научный центр психического здоровья РАМН.

Дюркгейм, Э. (2013). Самоубийство. Социологический этюд. СПб.: Союз.

Журавлева, Т. В., Ениколопов, С. Н., Зубарева, О. В., Черная, М. И. (2015а). Клинико-психологические особенности аддиктов с незавершенными суицидальными попытками. Психология и право, 5(4), 49-70.

Журавлева, Т. В., Чистопольская, К. А., Ениколопов, С. Н. (2015б). Отношение к суициду при антивитальных переживаниях. В кн. Н. Г. Незнанов (ред.), Психиатрия на этапах реформ: проблемы и перспективы. ХVI съезд психиатров России. Всероссийская научно-практическая конференция с международным участием (с. 891-892). СПб.: Альта Астра.

Лайнен, М. М. (2008). Когнитивно-поведенческая терапия пограничного расстройства личности. М.: Вильямс.

Леонтьев, Д. А., Рассказова, Е. И. (2006). Тест жизнестойкости. Методическое руководство по новой методике психологической диагностики личности с широкой областью применения. М.: Смысл.

Морев, М. В., Шматова, Ю. Е., Любов, Е. Б. (2014). Динамика суицидальной смертности населения России: Региональный аспект. Суищидология, 14(1), 3-11.

Осин, Е. Н., Рассказова, Е. И. (2013). Краткая версия теста жизнестойкости: психометрические характеристики и применение в организационном контексте. Вестник Московского университета. Серия 14. Психология, 2, 147-165.

Павлова, Т. С. (2013). Диагностика риска суицидального поведения детей и подростков в образовательных учреждениях. Современная зарубежная психология, 2(4), 79-91.

Сирота, Н. А., Ялтонский, В. М., Хажилина, И. И., Видерман, Н. С. (2001). Профилактика наркомании у подростков: от теории к практике. М.: Генезис.

Соколова, Е. Т. (2015). Клиническая психология утраты Я. М.: Смысл.

Сырцова, А., Митина, О. В. (2008). Возрастная динамика временных ориентаций личности. Вопросы психологии, 2, 41-54.

Харитонов, С. В., Чубина, С. А., Рызова, С. В., Соболев, В. А., Кушнарев, В. М. (2014). Результаты клинических испытаний опросника «Шкалы динамического контроля суицидального риска». Суицидология, 5(2), 20-25.

Харитонов, С. В., Рызова, С. В., Цупрун, В. Е. (2016). Пиктографический экспресс-тест «Риск суицидального действия». Суицидология, 7(2), 34-40.

Чистопольская, К. А., Ениколопов, С. Н. (2013). Проблема отношения к смерти после суицидальной попытки. Медицинская психология в России: электронный научный журнал, 2(19). Режим доступа: http://medpsy.ru/mprj/archiv_global/2013_2_19/nomer/nomer12.php 
Чистопольская, К. А., Ениколопов, С. Н. (2015). Отношение к смерти после попытки самоубийства: стигматизация и самостигматизация суицидальных пациентов. Вестник психиатрии и психологии Чувашии, 11(1), 8-20.

Чистопольская, К. А., Ениколопов, С. Н., Бадалян, А. В., Саркисов, С. А. (2012). Адаптация методик исследования отношения к смерти у людей в остром постсуициде и в относительном психологическом благополучии. Социальная и клиническая психиатрия, 22(2), 35-42.

Чистопольская, К. А., Ениколопов, С. Н., Николаев, Е. Л., Семикин, Г. И., Храмелашвили, В. В., Казанцева, В. Н., Журавлева, Т. В. (2014). Адаптация опросников «Отношение к смерти» и «Страх личной смерти» на русскоязычной выборке. Суицидология, 5(2), 60-69.

Шнейдман, Э. (2001). Десять общих черт самоубийств и их значение для психотерапии. В кн. А. Н. Моховиков (сост.), Суицидология: прошлое и настоящее: Проблема самоубийства в трудах философов, социологов, психотерапевтов и в художественных текстах (с. 353-359). М.: Когито-Центр.

Ссылки на зарубежные источники см. в разделе References после англоязычнго блока.
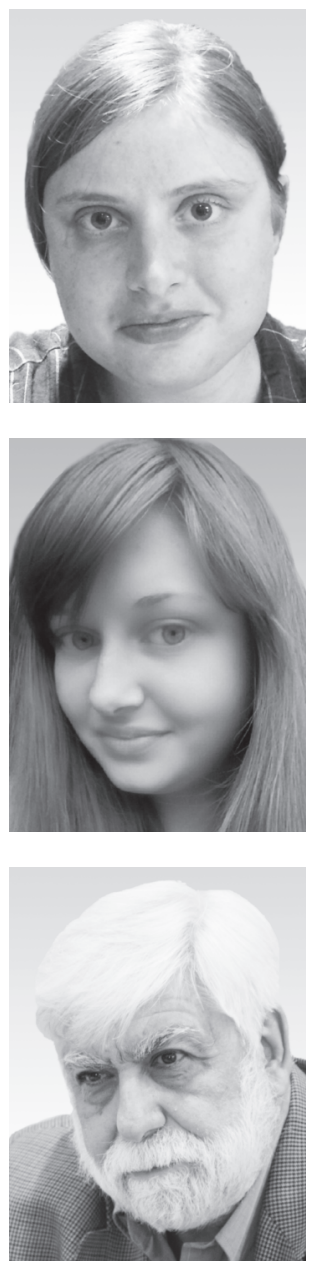

Чистопольская Ксения Анатольевна - младший научный сотрудник, отдел суицидологии, Московский научно-исследовательский институт психиатрии - филиал Федерального государственного бюджетного учреждения «Федеральный медицинский исследовательский центр психиатрии и наркологии» Министерства здравоохранения Российской Федерации.

Сфера научных интересов: суицидология, клиническая психология, психология личности.

Контакты: ktchist@gmail.com

Журавлева Татьяна Владимировна - студентка магистратуры, кафедра клинической и судебной психологии, факультет юридической психологии, Федеральное государственное бюджетное образовательное учреждение высшего образования «Московский государственный психолого-педагогический университет».

Сфера научных интересов: суицидология, клиническая психология, виктимология, судебная психология.

Контакты: tita1993@mail.ru

Ениколопов Сергей Николаевич - профессор, факультет психологии, Московский государственный университет имени М.В. Ломоносова; заведующий отделом медицинской психологии, федеральное государственное бюджетное научное учреждение «Научный центр психического здоровья», кандидат психологических наук.

Сфера интересов: клиническая психология, юридическая психология, криминальная психология, психология юмора.

Контакты: enikolopov@mail.ru 


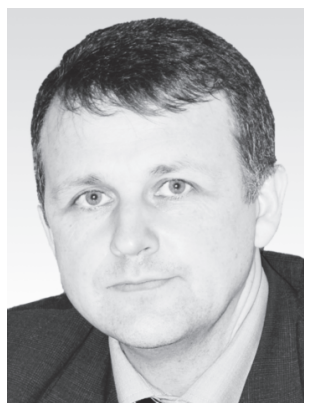

Николаев Евгений Львович - заведующий кафедрой социальной и клинической психологии, факультет управления и социальных технологий, Чувашский государственный университет им. И.Н. Ульянова, доктор медицинских наук.

Сфера научных интересов: психическое здоровье, социокультурные вопросы здоровья, аутодеструктивное поведение, адаптивный потенциал личности, психопрофилактика, психотерапия.

Контакты: pzdorovie@bk.ru

\title{
Adaptation of Diagnostic Instruments for Suicidal Aspects of Personality
}

\author{
Ksenia A. Chistopolskayaa, Tatiana V. Zhuravleva ${ }^{b}$, Sergey N. Enikolopov ${ }^{c}$, \\ Evgeni L. Nikolaev ${ }^{\mathrm{d}}$
}

\begin{abstract}
${ }^{a}$ Moscow Research Institute of Psychiatry - branch of the Federal State Institution "Federal Medical Research Centre of Psychiatry and Narcology" of the Ministry of Health of the Russian Federation, 3/10 Poteshnaya Str., Moscow, 107076, Russian Federation

${ }^{b}$ Moscow State University of Psychology and Educaion, 29 Sretenka Str., Moscow, 127051, Russian Federation

${ }^{c}$ The Mental Health Research Center, 34 Kashirskoe Highway, Moscow, 115522, Russian Federation

${ }^{d}$ Chuvash State University, 15 Moskovskiy Pr., Cheboksary, Chuvashia, 428010, Russian Federation
\end{abstract}

\begin{abstract}
The results of a Russian adaptation of the questionnaires The Psychache Scale (Holden et al., 2001), Reasons for Living Inventory (Linehan et al., 1983) and Reasons for Attempting Suicide Questionnaire (Johns, Holden, 1997) are presented. The translation was done and then mentally healthy people aged 16-26 were questioned (150 under- and postgraduate students and highschool youth in Moscow, 66 males, 84 females; and 221 undergraduate students in Cheboksary, 50 males, 171 females). Psychometric properties of the Russian versions of the adapted questionnaires showed good results in reproducibility of the factors' structures that constitute the questionnaires' scales, their reliability and construct validity. With the principal components method, varimax rotation, the satisfactory correspondence of the structure of the Russian versions of the questionnaires to the structure of the original versions is confirmed. After the follow-up revision the Russian versions of the questionnaires may be used for the assessment of the suicide risk and motivation of suicidal behavior in high-school youth and university students, as well as in research purposes to study the reasons for suicidal behavior.
\end{abstract}

Keywords: suicidal behavior, adaptation of the scales, internal consistency of the scales, reproducibility, validity. 


\section{References}

Aishvarya, S., Maniam, T., Karuthan, C., Sidi, H., Ruzyanei, N., Oei, T. P. S. (2014). Psychometric properties and validation of the Reasons for Living Inventory in an outpatient clinical population in Malaysia. Comprehensive Psychiatry, 55(1), S107-S113.

Alexis, M. M., \& Klonsky, F. D. (2013). Assessing motivations for suicide attempts: Development and psychometric properties of the inventory of motivations for suicide attempts. Suicide and LifeThreatening Behavior, 43(5), 532-546.

Ambrumova, A. G. (1978). Psikhalgiya v suitsidologicheskoi praktike [Psychache in suicidological practice]. In Aktual'nye problemy suitsidologii [Current issues of suicidology] (pp. 73-98). Moscow: Moscow Research Institute of Psychiatry.

Ambrumova, A. G., \& Kalashnikova, O. E. (1996). Psikhologicheskie aspekty odinochestva [The psychological aspects of loneliness]. Sotsial'naya i Klinicheskaya Psikhiatriya, 6(3), 53-63.

Ambrumova, A. G., \& Kalashnikova, O. E. (1998). Kliniko-psikhologicheskie aspekty samoubiistva [Clinical-psychological aspects of suicide]. Sotsial'naya i Klinicheskaya Psikhiatriya, 4(8), 65-77.

Bancroft, J. H. J., Skrimshire, A. M., \& Simkin, S. (1976). The reasons people give for taking overdoses. British Journal of Psychiatry, 128, 538-548.

Beck, A., \& Freeman, A. (2002). Kognitivnaya psikhoterapiya rasstroisto lichnosti. Praktikum po psikhoterapii [Cognitive psychotherapy of personality disorders. Practicum in psychotherapy]. Saint Petersburg: Piter. (Transl. of: Beck, A. T., \& Freeman, A. (1990). Cognitive therapy of personality disorders. New York: Guilford).

Beck, A. T., Weissman, A., Lester, D., \& Trexler, L. (1974). The measurement of pessimism: The Hopelessness scale. Journal of Consulting and Clinical Psychology, 42(6), 861-865.

Bogg, T., \& Roberts, B. W. (2004). Conscientiousness and health-related behaviors: A meta-analysis of the leading behavioral contributors to mortality. Psychological Bulletin, 130(6), 887-919.

Chistopolskaya, K. A., \& Enikolopov, S. N. (2013). The attitude to death: it is a problem after suicide attempt. Medical Psychology in Russia, 2(19). Retrieved from http://medpsy.ru/mprj/ archiv_global/2013_2_19/nomer/nomer12.php (in Russian)

Chistopolskaya, K. A., \& Enikolopov, S. N. (2015). Death attitudes after a suicide attempt: stigmatization and self stigmatization of suicidal patients. The Bulletin of Chuvash Psychiatry and Psychology, 11(1), 8-20. (in Russian)

Chistopolskaya, K. A., Enikolopov, S. N., Badalyan, A. V., \& Sarkisov, S. A. (2012). Adaptation of the attitude to death and fear of death assessment techniques for the healthy individuals and those in acute post-suicidal condition in a Russian sample. Sotsial'naya i Klinicheskaya Psikhiatriya, 22(2), 35-42. (in Russian)

Chistopolskaya, K. A., Enikolopov, S. N., Nikolaev, E. L., Semikin, G. I., Khramelashvili, V. V., Kazantseva, V. N., \& Zhuravleva, T. V. (2014). Adaptation of Death Attitude Profile-Revised and Fear of Personal Death Scale in Russian-speaking sample. Suicidology, 5(2), 60-69. (in Russian)

Choi, J. L., \& Rogers, J. R. (2010). Exploring the validity of the college student reasons for Living Inventory among Asian American college students. Archives of Suicide Research, 14(3), 222-235.

DeLisle, M. M., \& Holden, R. R. (2009). Differentiating between depression, hopelessness and psychache in university undergraduates. Measurement and Evaluation in Counseling and Development, 42, 46-63.

Durkheim, E. (2013). Samoubiistvo. Sotsiologicheskii etyud [Suicide. A sociological essay]. Saint Petersburg: Soyuz. (Transl. of: Durkheim, É. (1897). Le suicide. Étude de sociologie [Suicide. A sociological essay]. Paris: Félix Alcan. (in French)). 
Flamenbaum, R., \& Holden, R. R. (2007). Psychache as a mediator in the relationship between perfectionism and suicidality. Journal of Counseling Psychology, 54, 51-61.

Florian, V., \& Kravetz, S. (1983). Fear of personal death: Attribution, structure, and relation to religious belief. Journal of Personality and Social Psychology, 44, 600-607.

Garcia Valencia, J., Palacio Acosta, C. A., Vargas, G., Arias, S., Ocampo, M. V., Aguirre, B., ... Garcia, H. (2009). Validaciyn del inventario de razones para vivir (RFL) en sujetos con conducta suicida de Colombia. Revista Colombiana de Psiquiatria, 38(1), 66-84. (in Spanish)

Heisel, M. J., \& Flett, G. L. (2004). Purpose in life, satisfaction with life, and suicide ideation in a clinical sample. Journal of Psychopathology and Behavioral Assessment, 26, 127-135.

Hjelmeland, H., Hawton, K., Nordvik, H., Bille-Brahe, U., De Leo, D., Fekete, S., ... Wasserman, D. (2002). Why people engage in parasuicide: A cross-cultural study of intentions. Suicide and LifeThreatening Behavior, 32(4), 380-393.

Holden, R. R., \& DeLisle, M. M. (2006). Factor structure of the Reasons for attempting Suicide Questionnaire (RASQ) with suicide attempters. Journal of Psychopathology and Behavioral Assessment, 28, 1-8.

Holden, R. R., \& Kroner, D. G. (2003). Differentiating suicidal motivations and manifestations in a forensic sample. Canadian Journal of Behavioral Science, 35, 35-44.

Holden, R. R., \& McLeod, L. D. (2000). The structure of the Reasons for Attempting Suicide Questionnaire (RASQ) in a nonclinical adult population. Personality and Individual Differences, 29, 621-628.

Holden, R. R., Mehta, K., Cunningham, E. J., \& McLeod, L. D. (2001). Development and preliminary validation of a scale of psychache. Canadian Journal of Behavioral Science, 33, 224-232.

Johns, D., \& Holden, R. R. (1997). Differentiating suicidal motivations and manifestations in a nonclinical population. Canadian Journal of Behavioral Science, 29, 266-274.

Kharitonov, S. V., Chubina, S. A., Ryzova, S. V., Sobolev, V. A., \& Kushnariov, V. M. (2014). Results from clinical trials questionnaire "Scales dynamic control of suicidal behavior". Suicidology, 5(2), 20-25. (in Russian)

Kharitonov, S. V., Ryzova, S. V., \& Tzuprun, V. E. (2016). Pictographic rapid test is "the Risk of suicidal actions". Suicidology, 7(2), 34-40. (in Russian)

Leontiev, D. A., \& Rasskazova, E. I. (2006). Test zhiznestoikosti [Hardiness Survey]. Moscow: Smysl.

Levinger, Sh., \& Holden, R. R. (2014). Reliability and validation of the Hebrew version of the Reasons for Attempting Suicide Questionnaire (RASQ-H) and its importance for mental pain. Suicide and Life-Threatening Behavior, 44(1), 13-18.

Linehan, M. M. (2008). Kognitivno-povedencheskaya terapiya pogranichnogo rasstroistva lichnosti [Cognitive-behavioral therapy of borderline personality disorder]. Moscow: Vil'yams. (Transl. of: Linehan, M. M. (1993). Cognitive-behavioral treatment of borderline personality disorder. New York: Guilford Press).

Linehan, M. M., Goodstein, J. L., Nielsen, S. L., \& Chiles, J. A. (1983). Reasons for staying alive when you are thinking of killing yourself: The Reasons for Living Inventory. Journal of Consulting and Clinical Psychology, 51, 276-286.

Maddi, S. (2004). Hardiness: An operationalization of existential courage. Journal of Humanistic Psychology, 44(3), 279-298.

Malone, K. M., Oquendo, M. A., Haas, G. L., Ellis, S. P., Li, S., \& Mann, J. J. (2000). Protective factors against suicidal acts in major depression reasons for living. American Journal of Psychiatry, 157(7), 1084-1088.

Meerwijk, E. L., \& Weiss, S. J. (2016). Does suicidal desire moderate the association between frontal delta power and psychological pain? Peer Journal, 1, 1-16. 
Mills, J. F., Green, K., \& Reddon, J. R. (2005). An evaluation of the Psychache Scale on an offender population. Suicide and Life-Threatening Behavior, 35, 570-580.

Morev, M. V., Shmatova, Yu. E., \& Lyubov, E. B. (2014). Dynamics of suicide mortality in Russia: the Regional level. Suicidology, 14(1), 3-11. (in Russian)

Olié, E., Guillaume, S., Jaussent, I., Courtet, P., \& Jollant, F. (2010). Higher psychological pain during a major depressive episode may be a factor of vulnerability to suicidal ideation and act. Journal of Affective Disorders, 120, 226-230.

Orbach, I., Mikulincer, M., Gilboa-Schechtman, E., \& Sirota, P. (2003). Mental pain and its relationship to suicidality and life meaning. Suicide and Life-Threatening Behavior, 33, 231-241.

Osin, E. N., \& Rasskazova, E. I. (2013). A short version of the Hardiness Test: Psychometric properties and organizational application. Vestnik Moskovskogo Universiteta. Seriya 14. Psikhologiya, 2, 147-165.

Osman, A., Downs, W. R., Kopper, B. A., Barrios, F. X., Baker, M. T., Osman, J. R., ... Linehan, M. M. (1998). The Reasons for Living Inventory for Adolescents (RFL-A): development and psychometric properties. Clinical Psychology, 54(8), 1063-1078.

Patterson, A. A., \& Holden, R. R. (2012). Psychache and suicide ideation among men who are homeless: a test of Shneidman's model. Suicide and Life-Threatening Behavior, 42, 147-156.

Pavlova, T. S. (2013). Diagnostics of suicidal behavior risks of children and adolescents in educational institutions. Journal of Modern Foreign Psychology, 2(4), 79-91. (in Russian)

Pereira, E. J., Kroner, D. G., Holden, R. R., \& Flamenbaum, R. (2010). Testing Shneidman's model of suicidality in incarcerated offenders and in undergraduates. Personality and Individual Differences, 49, 912-917.

Peters, M. (2011). Translating patient reported outcome measures (PROMs) for cross-cultural studies. In C. Jenkinson, M. Peters, \& M. Bromberg (Eds.), Quality of life measurement in neurodegenerative and related conditions (pp. 139-146). New York: Cambridge University Press.

Pyszczynski, T., \& Kesebir, P. (2011). Anxiety buffer disruption theory: A terror management account of posttraumatic stress disorder. Anxiety, Stress and Coping: An International Journal, 24(1), 3-26.

Ribeiro, J. D., Witte, T. K., Van Orden, K. A., Selby, E. A., Gordon, K. H., Bender, T. W., \& Joiner, T. E. (2014). Fearlessness about death: The psychometric properties and construct validity of the revision to the Acquired Capability for Suicide Scale. Psychological Assessment, 26(1), 115-126.

Ronconi, L., Testoni, I., \& Zamperini, A. (2009). Validation of the Italian version of the Reasons for Living inventory. Testing, Psychometrics, Methodology in Applied Psychology, 16(3), 151-159.

Shneidman, E. (2001). Desyat' obshchikh chert samoubiistv i ikh znachenie dlya psikhoterapii [The ten general characteristics of suicide and their importance for psychotherapy]. In A. N. Mokhovikov (Ed.), Suitsidologiya: proshloe i nastoyashchee: Problema samoubiistva v trudakh filosofov, sotsiologov, psikhoterapevtov iv khudozhestvennykh tekstakh [Suicidology: Past and present: The problem of suicide in the works of philosophers, sociologists, psychotherapists and in literature] (pp. 353-359). Moscow: Kogito-Tsentr.

Sirota, N. A., Yaltonskii, V. M., Khazhilina, I. I., \& Viderman, N. S. (2001). Profilaktika narkomanii u podrostkov: ot teorii $k$ praktike [Prophilaxis of narcomania in teen-agers: from theory to practice]. Moscow: Genezis.

Sokolova, E. T. (2015). Klinicheskaya psikhologiya utraty Ya [Clinical psychology of the loss of Self]. Moscow: Smysl.

Soubrier, J.-P. (1993). Definitions of suicide. In A. A. Leenaars (Ed.), Suicidology: Essays in honor of Edwin S. Shneidman (pp. 35-41). Northvale, NJ: Jason Aronson Inc.

Stravynski, A., \& Boyer, R. (2001). Loneliness in relation to suicide ideation and parasuicide: A population-wide study. Suicide and Life-Threatening Behavior, 31(1), 32-40. 
Syrtsova, A., \& Mitina, O. V. (2008). Developmental dynamics of temporal orientations of personality. Voprosy Psikhologii, 2, 41-54. (in Russian)

Troister, T., D'Agata, M. T., \& Holden, R. R. (2015). Suicide risk screening: comparing the Beck Depression Inventory-II, Beck Hopelessness Scale, and Psychache Scale in undergraduates. Psychological Assessment, 27(4), 1500-1506.

Voitsekh, V. F. (2007). Chto my znaem o suitside [What we know of suicide]. Moscow: The Mental Health Research Center.

Vreeman, R. C., McHenry, M. S., \& Nyandiko, W. M. (2013). Adapting health behavior measurement tools for cross-cultural use. Journal of Integrative Psychology and Therapeutics. Retrieved from http://www.hoajonline.com/journals/pdf/2054-4723-1-2.pdf

Wong, P. T., Reker, G. T., \& Gesser, G. (1994). Death-Attitude Profile-Revised: A multidimensional measure of attitudes toward death. In R. Neimeyer (Ed.), Death anxiety handbook: Research, instrumentation, and application (pp. 121-148). New York: Taylor and Francis.

Zhuravleva, T. V., Chistopolskaya, K. A., \& Enikolopov, S. N. (2015b). Otnoshenie k suitsidu pri antivital'nykh perezhivaniyakh [An attitude toward suicide in antivital states]. In N. G. Neznanov (Ed.), Psikhiatriya na etapakh reform: problemy i perspektivy. XVI s"ezd psikhiatrov Rossii. Vserossiiskaya nauchno-prakticheskaya konferentsiya s mezhdunarodnym uchastiem [Psychiatry at the stage of reforms: problems and perspectives. XVI convention of psychiatrists of Russia. AllRussian scientific-practical conference with international participation] (pp. 891-892). Saint Petersburg: Al'ta Astra.

Zhuravleva, T. V., Enikolopov, S. N., Zubareva, O. V., \& Chernaia, M. I. (2015a). Clinical and psychological features of addict people with an incomplete suicide attempt. Psikhologiya i Pravo, 5(4), 49-70. (in Russian)

Zimbardo, P., \& Boyd, J. (1999). Putting time in perspective: A valid, reliable individual-differences metric. Journal of Personality and Social Psychology, 77(6), 1271-1288.

Zimet, G. D., Dahlem, N. W., Zimet, S. G., \& Farley, G. K. (1988). The Multidimensional Scale of Perceived Social Support. Journal of Personality Assessment, 52(1), 30-41.

Kseniya A. Chistopolskaya - junior research fellow, Department of Suicidology, Moscow Research Institute of Psychiatry - branch of the Federal State Institution "Federal Medical Research Centre of Psychiatry and Narcology" of the Ministry of Health of the Russian Federation. Research area: suicidology, clinical psychology, psychology of personality.

E-mail: ktchist@gmail.com

Tatiana V. Zhuravleva - student, magistracy of Department of Clinical and Judicial Psychology, Faculty of Legal Psychology, Moscow State University of Psychology\&Educaion.

Research area: suicidology, clinical psychology, victimology, forensic psychology.

E-mail: tita1993@mail.ru

Sergey N. Enikolopov - head of the Department of Clinical Psychology, The Mental Health Research Center, Ph.D., professor.

Research area: clinical psychology, forensic psychology, victimology, psychology of humor.

E-mail: enikolopov@mail.ru

Evgeni L. Nikolaev - head of the chair of Social and Clinical Psychology, Department of Management and Social Technologies, Chuvash State University, D.Sc.

Research area: Mental health, sociocultural health issues, autodestructive behavior, adaptive personality potential, psychoprophylaxis, psychotherapy.

E-mail: pzdorovie@bk.ru 